Article

\title{
Auckland's Urban Sprawl, Policy Ambiguities and the Peri-Urbanisation to Pukekohe
}

\author{
Cristian Silva \\ School of Architecture and Planning, University of Auckland, Auckland 1010, New Zealand; \\ ca.silva@auckland.ac.nz; Tel.: +64-9232829 \\ Received: 10 November 2018; Accepted: 17 December 2018; Published: 21 December 2018
}

\begin{abstract}
Urban sprawl has been discussed extensively with regard to its negative impacts. On this basis, regulations have been put in place to control sprawling suburbanization, including the establishment of restricted areas for expansion defined by administrative urban boundaries. Overall, these measures have not been at all successful, considering that city-regions continue to expand inorganically, often reinforcing urban sprawl patterns. As clear evidence of the weaknesses of planning regimes of control, these unsuccessful attempts are partly explained by a series of policy ambiguities that contradict the meaning of planning as a prescriptive discipline. This ambiguity is justified by the need to frame flexible regulations that allow adaptation to unforeseen events over time. In this paper, using the case of Auckland, New Zealand, it is demonstrated that instead of planning flexibility, there is planning "ambiguity" accompanied by weak opposition from rural regimes, which deliberately contributes to urban sprawl. This is relevant considering that the inorganic encroachment of rural lands diminishes the huge environmental potential of the peri-urban space of Auckland, its ecosystem services, and agricultural activities-all elements that encourage the creation of more environmentally sustainable peripheral landscapes as a counterpoint to traditional sprawling suburbanization.
\end{abstract}

Keywords: urban sprawl; planning policy; peri-urbanization; rural lands; Auckland; Pukekohe

\section{Introduction}

Urban sprawl has been discussed mainly in terms of population growth, suburban inertia and improvements to transport infrastructure [1]. The aim of this paper is to demonstrate that urban sprawl is not merely an outcome of population growth and improvements in transportation, but also the expression of conceptual and instrumental planning ambiguities that do not acknowledge the environmental assets situated at the peri-urban space, and their value in preventing the impacts of sprawl or modifying its unsustainable character [2].

In the case of Auckland and other city-regions, control of urban sprawl has relied on restrictions to urban growth [3], accompanied by narratives of urban sustainability [4], livability [5], compactness [6], urban regeneration [7] and increments of suburban density [8]. However, these attempts are undermined by more structural drivers of suburbanization, such as the persistent desire to live near the countryside [9], high rates of car dependency [10], housing affordability [11], lack of control of the land market [12], and the underestimation of rural assets [13]. Indeed, suburban sprawl is somehow enhanced rather than reduced by regulatory frameworks. This situation is clearly evident in most cities, where persistent urban sprawl contradicts politically correct anti-growth narratives. Auckland is no exception, considering that policy intensions are explicit in promoting more environmentally sustainable urban growth, but suburbanization is consolidating traditional sprawling patterns. This disparity between policy intensions and suburban sprawl is particularly significant in Auckland, as most of its peri-urban space is composed of highly productive agricultural lands that 
clearly contribute to the country's economy and its rural identity. More specifically, it has become critical in the southern area of Auckland near the small town of Pukekohe, where extremely fertile soils and valuable environmental assets are already scheduled for housing intensification [14].

It is important to emphasize that Auckland's suburban space is privileged by a varied natural landscape that includes several port areas, waterfronts, large parks, lakes, forests, beaches and farming spaces with animal husbandry and horticulture. However, the urban morphology and infrastructural response to this variation is almost absent, and the built environment is characterized by detached houses, domestic carports (usually for two cars or more), roads, street lights, car sale yards, fast-food outlets, shopping malls with large car-parking areas and inner highways (Figure 1). These are the most common spatial elements across the city, with the exception of the Central Business District (CBD). Planning regulations do not specify what the urban form should be, and therefore a relatively homogenous morphology is configured, with slight variations on architectural nuances of different kinds [15].

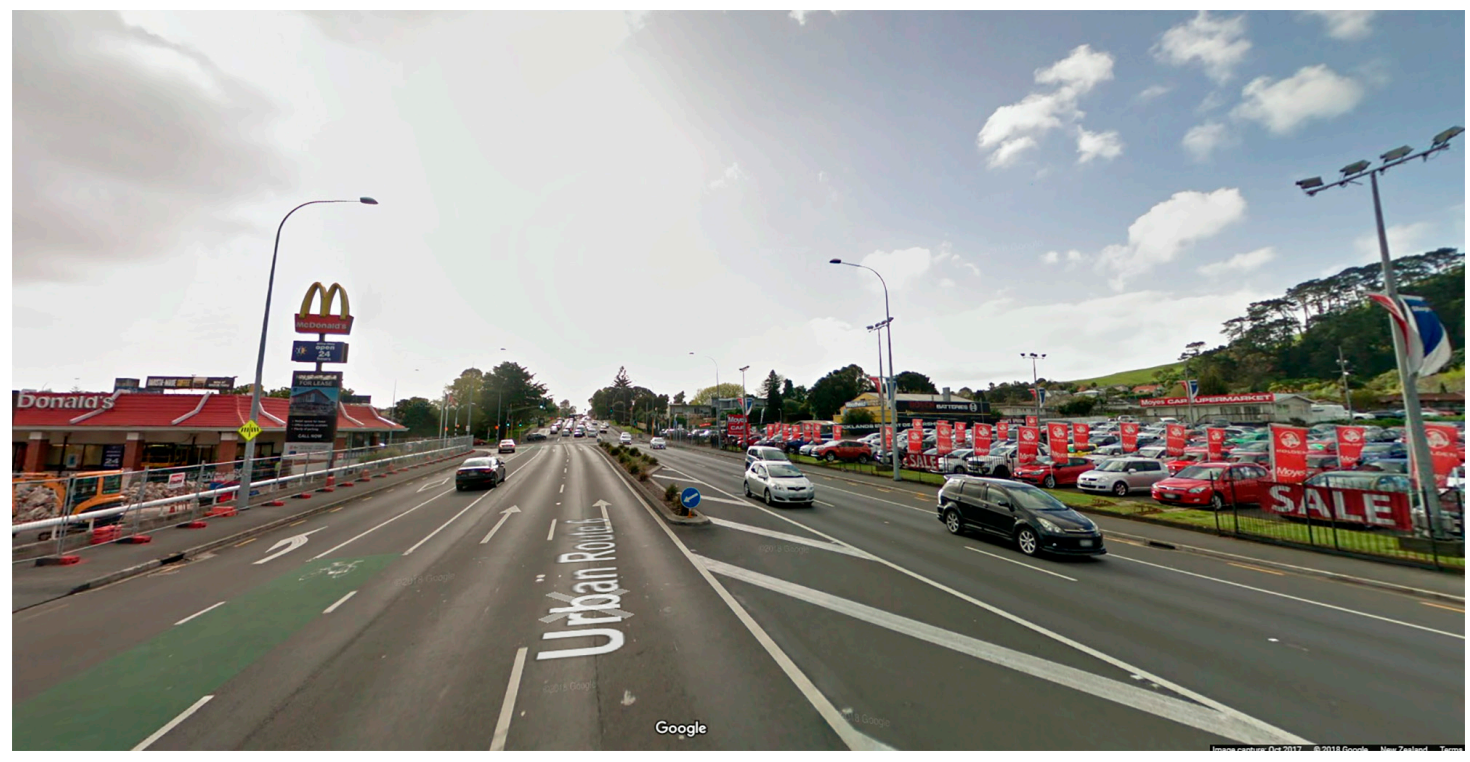

Figure 1. A view of the Ellerslie-Panmure Highway, a typical suburban connection in the suburb of Panmure (Google Street view retrieved in November 2018).

Considering what is argued by the Auckland Unitary Plan (i.e., the leading planning document delivered by the Auckland Council), land prices around Pukekohe allow for the provision of affordable houses. Further, infrastructural improvements and the weak opposition of rural regimes that support land-use changes in response to proximity to the city also affect decision-making [13]. In this paper, it is demonstrated that Auckland's urban sprawl relies on these planning ambiguities and the asymmetric relationship between urban and rural regimes of control, whereby flexible restrictions on rural space barely restrain inorganic urban expansion. On this basis, it is suggested that more sustainable urban development of Auckland-rather than simply relying on anti-growth narratives-might include the urban-rural dynamics that operate upon the transformation of peri-urban spaces and consider them as a rich source of environmental assets that can inform a more appropriate planning approach. Finally, it is suggested that in the context of policy-ambiguity, understanding urban sprawl and the peri-urban space from the gateways of political ecology, environmental services, natural capital, green infrastructure and urban agriculture, inter alia, may contribute to the improvement of planning frameworks and inspire solutions in urban design, landscape planning and architecture for the configuration of more sustainable peri-urban landscapes.

In the theoretical section, I discuss the ambiguity around the notion of "urban sprawl" and its determinants in order to highlight the lack of attention to its rural dimension. I also discuss some international studies in which suburban rurality has been addressed through both policy-based 
and morphological approaches to planning. I then present the methodology, including the context of analysis, the case study, and how the empirical data were collected and analysed. The results and discussion emphasize the planning ambiguities in Auckland's planning policy. Finally, in the concluding section, the findings are summarized to suggest that control of urban sprawl in Auckland needs to consider the valuable rural forces and environmental assets of the peri-urban landscape, and counter the consolidation of its sprawling condition.

\section{Theoretical Background}

\subsection{The Ambiguous and Contested Nature of Urban Sprawl}

"Urban sprawl" is a term generally used to describe most patterns of urban growth in almost all cities, and is accepted as an expression of inorganic urban development [16]. However, the range of factors that describe and explain urban sprawl is still under debate, as its mere definition appears contested and difficult to fix [17]. More specialized literature indicates that not all patterns of urban growth can be properly labelled as instances of "urban sprawl" [18]. Aside from these differing positions, "urban growth" as "urban sprawl" follows two streams of argument. On the one hand is the idea of dispersed suburbanization driven by the increasing use of private cars, stimulated by the construction of motorway systems [19], and on the other, the increasing demand for living near the countryside, known as "suburbanization" [20]. A morphological consensus describes urban sprawl as being largely characterized by low-density residential neighbourhoods, regional transport infrastructure, car dependency, single land-uses and lack of physical continuity [21]. Some technical studies suggest that a set of indicators is crucial to determining a "sprawl index" to use in identifying an urban area as being in a sprawling condition [22]. As such, urban sprawl is highly criticized for its environmental, social and economic impacts [23]. Some argue that morphological descriptions are insufficient to analyse "urban sprawl", and more policy-based factors are suggested for analysis, including land-use conversion, population change, traffic and vehicle miles travelled, energy consumption and fiscal measures [24].

An extra constraint on understanding urban sprawl relates to its strong "urban" focus [1]. However, emerging literature links urban sprawl with the transformation of fringe-belt areas not purely driven by urban forces. It appears to be a non-exclusive urban issue, which embraces urban-rural interactions depicted by mixed landscapes composed of urban and rural lands. The notion of "urbanized countryside" [25], for instance, describes this ambiguous urban-rural transition as a new geography which is neither solely urban nor rural, but embraces characteristic of both. In this light, urban sprawl and peri-urban areas are conceptually problematic because urban and rural activities take place in the same geographical space [26]. This suggests that urban sprawl is not merely an extension of suburbia over the rural space, but a distinctive geographical category where different institutional representations coexist [27]. This clarification is relevant because urban sprawl is nevertheless a continuous incorporation of peri-urban lands, and thus a process that should be assessed more according to its dynamics rather than its static morphological fragmentation [28].

It is important to note that these terms—suburbia, urban sprawl and peri-urban areas-sometimes cause confusion, as they are related. However, their meanings and spatial manifestations are completely different. For the purposes of this paper, suburban and peri-urban areas are constitutive of urban sprawl-the umbrella term. Here, suburbia refers to the urban structure resulting from the process of "suburbanization" [27], and is highly dependent on the consolidated city, while peri-urban is defined as the spatial structure resulting from processes of peri-urbanization that configure the urban-rural interface [29]. In contrast to suburbia (mainly residential), the peri-urban space is characterized by a mix of functions that include farming areas, but also industrial, residential and ecological reservoirs [20]. In this light, planning for "suburbia" can differ from the regulations that operate on farming or industrial areas at the peri-urban space. Finally, and as a matter of consensus, it is possible to agree that "the peri-urban is the area between urban settlement areas and their rural hinterland. 
Larger peri-urban areas can include towns and villages within an urban agglomeration. Such areas are often fast changing, with complex patterns of land use and landscape, fragmented between local or regional boundaries" $[10,29]$.

In many cases, the peri-urban space changes rapidly because of the population and employment growth and spatial re-structuring triggered by new infrastructure. However, in other cases, it is carefully managed and preserved [29]. Successful management is a difficult proposition, considering that urban growth is not always well provided with services and infrastructure. This is the case for Latin American and Asian cities, for instance, in which almost purely residential urban growth configures distinctive (sub)urban landscapes. As García-Ayllón argues, "the capacity to 'digest' this growth by large cities of Asia and Latin America has been limited. This phenomenon is the basis of the configuration of new patterns of urban development and landscape settings, ranging from the introduction of simplistic and repetitive patterns in Mexico City to the sudden creation of new cities with skyscrapers in China" [30]. This is partly supported by empirical studies in Chinese cities that have concluded that planning is strongly correlated withm urban sprawl patterns [31]. In a different vein, but still stressing the idea that urban sprawl is an ambiguous, diverse and contested geographical space, some authors have illustrated how capitalist policies have influenced suburbanization in Eastern European cities, and contributed to the general economic growth and increments of infrastructure. However, at a regional and metropolitan scale, the same growth has translated spatially into the creation of segregated suburban areas, the emergence of peri-urban "ghettos" and other expressions of socio-territorial disparity [32].

As a dynamic process, urban sprawl describes different configurations over time. It can manifest as different levels of land fragmentation, functionality and spatial diversity, even within the same urban region [29]. This heterogeneity can be seen as an advanced process of suburbanization characterized by increasing functional self-sufficiency, concentration of employment and a certain degree of disconnection from traditional urban centres [33]. Similarly, contemporary peri-urban boundaries appear as scenarios for emerging patterns of "polycentricism" that attract population and employment growth [34]. At a regional scale, the term "multi-functionality" describes sprawling and peri-urban areas as a complex mix, where different urban activities are linked to rural functions [2]. These spaces are more multifaceted — beyond residential land-uses—and include conurbation zones and satellite towns as part of wider urban-regional systems [35]. This varied character of urban sprawl is seen as an outcome of advanced capitalist processes where asymmetric institutional relations delay planning reactions and leave instruments of control lagging behind de facto situations [36]. In this context, successful land management relies on individual leadership rather than technical solutions or macro-scale plans that often encourage urban sprawl by omission [37]. Indeed, anti-growth narratives view sprawl as "unplanned", evincing its unintended nature driven by unforeseen forces [38]. Therefore, a closer inspection of planning instruments is needed to provide a clearer understanding of the extent to which urban sprawl is implicitly driven by the very same instruments that aim to control it.

\subsection{Urban Sprawl, Its Rural Dimension, and Planning Policies of Control}

Empirical studies suggest that causes of urban sprawl are mainly linked to housing policies, land market constraints and infrastructure [39]. These studies, however, are limited to European and monocentric city models characterized by clear relations between land fragmentation, land prices and income growth [40]. Social factors such as rates of crime in central areas and the proximity of rural lands to urban markets also encourage disperse suburbanization [41]. Whatever the case, the following planning determinants are clearly identified in the literature as encouraging urban sprawl: regional transport infrastructure and the persistence of the so-called "suburban dream" [20]; cheap prices for rural land [11]; implementation of "urban limits" (and other urban growth restrictions) [3]; conurbation zones [42]; the absence of urban regeneration and resilience policies [43]; weak taxation measures on empty (undeveloped) lands [44]; and institutional asymmetries between urban and rural 
representation [45]. The last determinant (i.e., the asymmetric rural-urban relationship) entails further exploration in terms of suburban governance specifically related to the potential autonomy of the peri-urban space and the institutional scope required to harmonize urban and rural interactions.

The persistent focus on discussing urban sprawl as an "urban" phenomenon is another constraint on comprehending the nature of sprawl. Traditionally, the built-up geography of sprawl is seen as the main object of inspection, as it reflects the forces behind the production of space [46]. However, the morphological fragmentation of urban sprawl cannot be considered without reference to the series of interstitial spaces that lie between developments, in which rural areas appear as a contested field of political, social, environmental and economic benefits [47]. This is partly because suburban rural lands do not present major physical restrictions to urbanization, and, at the same time, their condition as open space is perceived as undeveloped or simply inert [2]. In this vein, differing positions are driven by views of suburban rural lands as scenarios for densification or preservation [48]. In terms of the preservation of suburban rurality, debates on peri-urbanization and the configuration of fringe/belt areas create practical difficulties in delimitating "the urban" [49].

A few successful attempts to integrate "the urban" and "the rural" are currently framed by some macro-scale plans, such as the "Five-Finger Plan" of Copenhagen [50] and the "Green-Heart" project in the Netherlands [51]. In these plans, the open countryside is integrated into the urban scope in different ways. In the case of Copenhagen, its morphological definition allows the alternation of built-up areas with "open wedges". The inclusion of nature and the rural space as valuable assets has consolidated long-term territorial policies where "the rural" appears as embedded within "the urban" $[25,26]$, configuring a complex peri-urban space manifested as both as external and internal to the city (Figure 2).
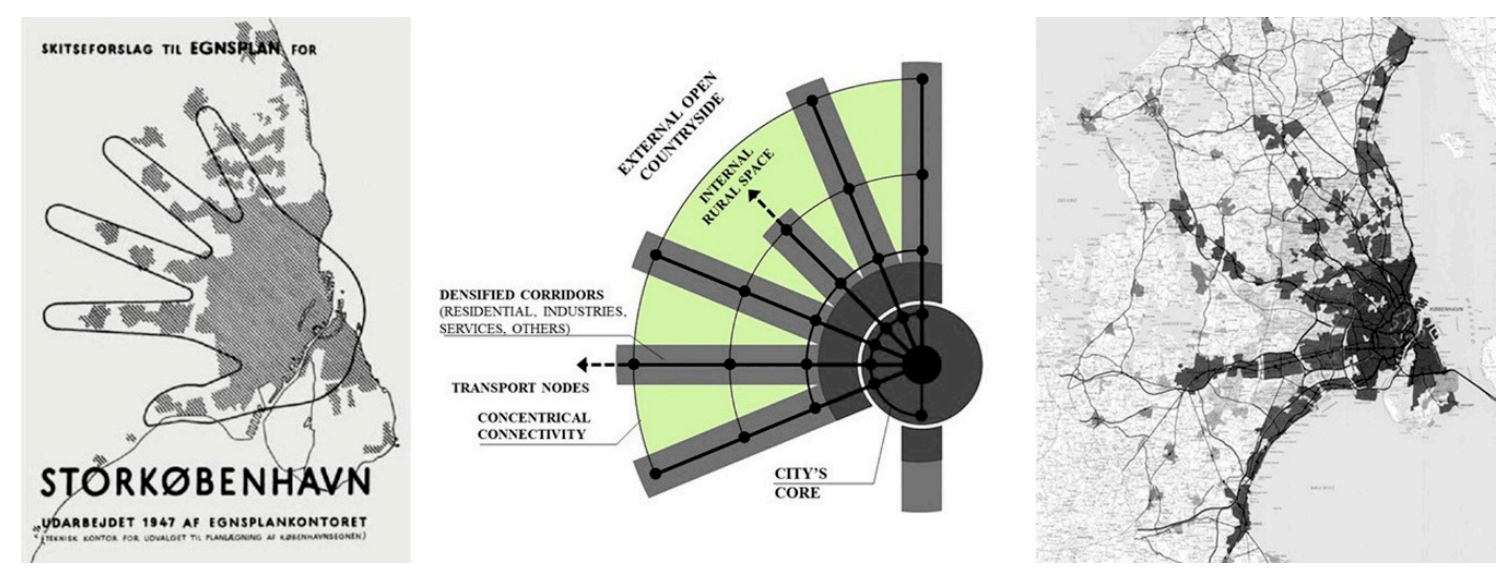

Figure 2. Map and diagrams of greater Copenhagen. (left) The original plan illustrating the morphological analogy of a "hand with fingers". (middle) An abstraction of the general urban form composed of "open wedges" and densified corridors. (right) A map of Copenhagen (Author's image).

The Randstad zone in the Netherlands is another case-in-point. This is a regional urbanized area morphologically configured as a "ring" composed of the main cities of Rotterdam, The Hague, Amsterdam and Utrecht, and several towns in between. These urban areas circumscribe a large piece of countryside known as the "Green-Heart", which supports agricultural production. Furthermore, between the cities and towns there are several small-scale rural spaces that host agricultural and public activities including parks, urban farmlands and ecological reservoirs (Figure 3). In this case, both the public and private sectors value well-located rural spaces and keep them as mechanisms for land-value capture, and as attractors of services and transport infrastructure [52,53]. These two scales differ in terms of planning regulations. While conurbation zones are flexible in promoting new developments, the Green-Heart is strongly regulated. The key planning principle is that natural landscapes are "infrastructures" that deserve a similar status as bridges, motorways or residential neighbourhoods. This means that rural spaces dispute their position in the planning agenda at the 
same level as traditional infrastructure, and are equally recognized as "landmarks" along with other outstanding architectural buildings. Indeed, the national planning policy recognizes 35 icons of Dutch spatial planning, and 17 of them are rural landscapes [54].
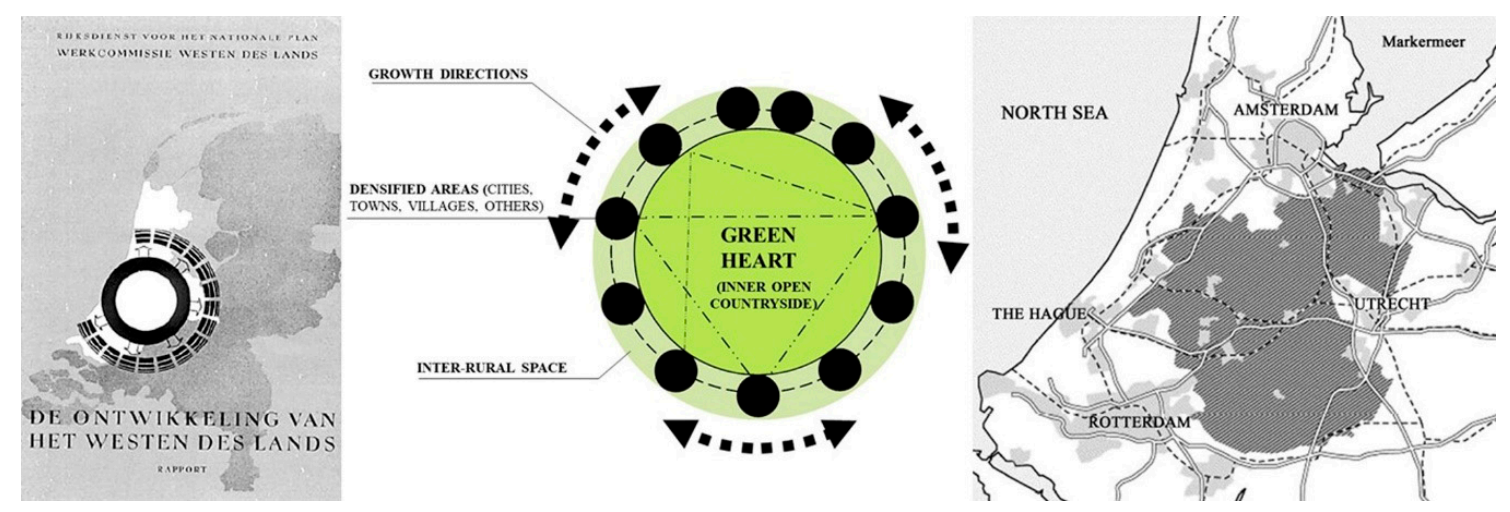

Figure 3. Map and diagrams of Randstad zone. (left) The original plan illustrating the "ring-city". (middle) An abstraction of the general urban form composed of the urbanized ring and the "Green-Heart". (right) Map of the Randstad zone (Author's image).

Despite these examples, there is no agreement on the extent to which protected rural lands are the outcome of well-defined planning frameworks, or random restrictions derived from physical constraints [49]. For some, the "open wedges" of the Finger Plan are mere morphological coincidences determined by geographical and physical impediments to urbanization (i.e., flood areas and others). In any case, these examples highlight the planned and unplanned nature of suburban rurality regardless of its intrinsic environmental value and the ecological content associated with prospects for ecological modernization [54]. It is clear that these comprehensive attempts are not standard practice in planning, and suburban rural lands are constantly subdued by urbanization. This confirms the pending nature of suburban rurality, as well as the "muddling through" rationale in which suburban sprawl is constantly constituted case-by-case.

\section{Methodology}

The material presented in this paper is the outcome of a qualitative research study aimed at explaining the role of urban and rural policies in promoting Auckland's urban sprawl. The sprawling condition of the city is usually denied, or at least absent from planning narratives, as it carries negative connotations usually linked to developing countries or inefficient planning regimes mainly dominated by market trends [10]. Indeed, Auckland is usually portrayed as one of the most livable cities in the world in mass media rankings, clearly obscuring structural indicators for quality of life linked to social and economic issues [55,56]. For instance, Auckland is one of the least affordable cities in the world for home ownership [57], and has one with the highest rates of car dependency, low use of public transport and critical problems with motorway congestion [58]. The city also suffers from a longstanding housing shortage [11], low-quality housing, increasing rates of socio-residential segregation, and socio-territorial disparities that consolidate longstanding patterns of gentrification [59]. These factors are to a great degree embedded in planning ambiguities, as they enable traditional urban sprawl and its consequences. Considering this, a qualitative approach is adopted to examine planning narratives and policy conflicts that give effect to Auckland's extended suburbanization and its consequences.

\subsection{Context of Analysis and the Case Study}

Auckland is the largest city in New Zealand, with 1.4 million residents. It is located in the North Island, and is recognized as the fastest-growing region in the country [60]. The city is characterized as an attractor of business, tourists and migrants, and for contributing almost the $40 \%$ of the country's GDP [61]. It is important to note that Auckland is currently a metropolitan region 
formed by several districts under a relatively new umbrella regulation. In 2009, Auckland underwent a major reform in governance through the amalgamation of eight territorial authorities. The purpose was to centralize decision-making, avoid fragmentation of governance and generate a more integrated planning framework to deliver transport infrastructure, improve community engagement and optimize consenting processes $[62,63]$. This reform defined one unitary authority, one regional council (the Auckland Council), and one integrated planning framework based on one spatial plan (strategic plan) and one district plan (statutory development control plan). In this context, the Franklin District in the south was included to contribute to regional development through its high agricultural capacity, as it produces most of the vegetables in the region [13]. This is relevant, as at the same time, the Franklin District was targeted to receive the largest level of population growth linked to improvements in transport infrastructure and the location of new housing developments. Although its sprawling character can be observed in all directions, Auckland's sprawl is particularly apparent in the ongoing suburbanization of the Franklin District, and specifically of Pukekohe, a small town surrounded by the most fertile lands of the whole region, situated $50 \mathrm{~km}$ from Auckland's CBD. Pukekohe is incorporated into the Auckland Unitary Plan as a satellite town, and most of its surrounding lands are zoned for housing intensification (Figure 4) [60].

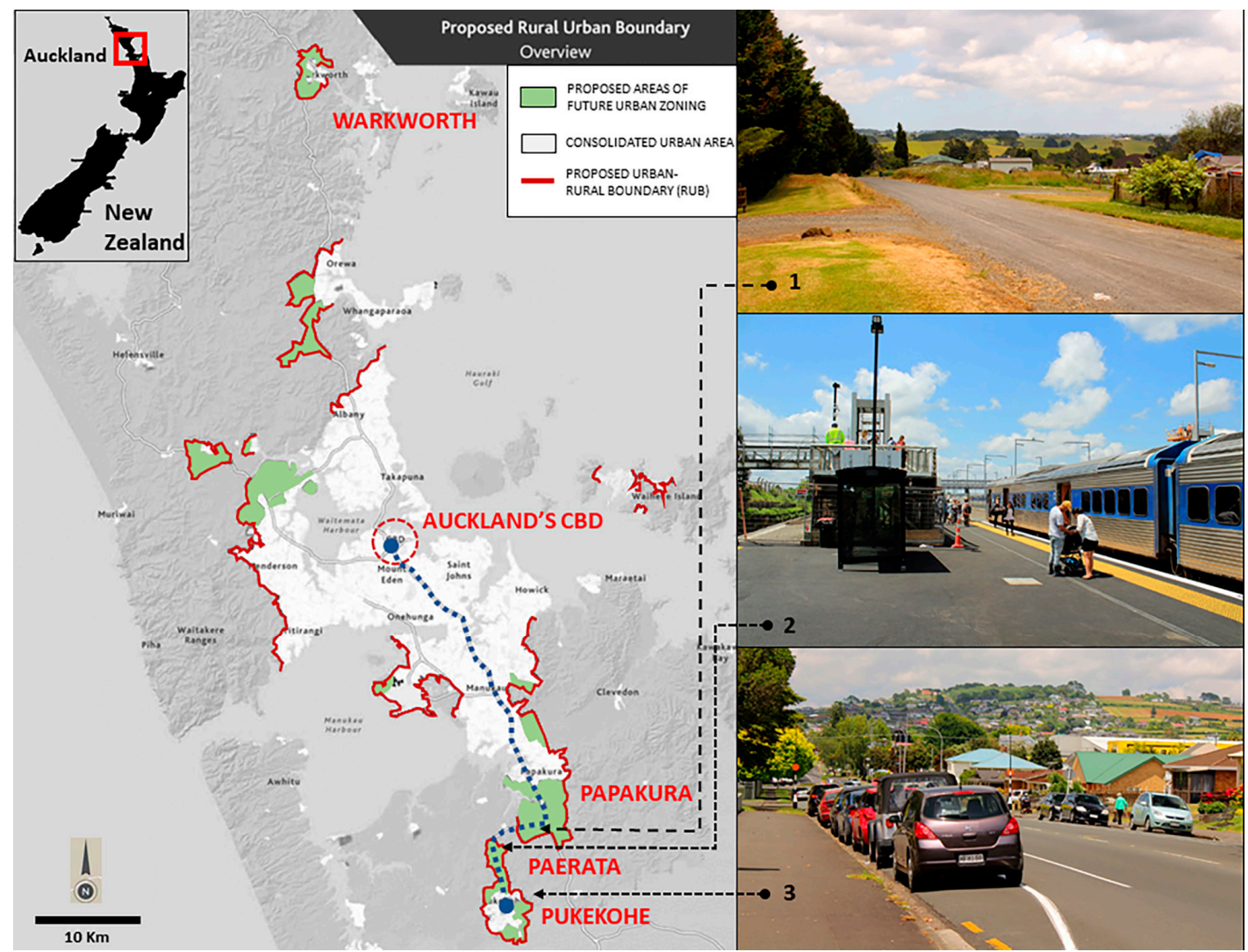

Figure 4. Map of Auckland, its urban boundaries and future areas of expansion (Author's map and photos, October 2017).

According to the Pukekohe Area Plan [64], the Franklin Local Board is able to provide direction on zoning and urban limits on the basis that "Pukekohe will be a vibrant and dynamic satellite town offering a range of employment and residential opportunities, with excellent transport connections, infrastructure, open space and recreation facilities, and a thriving local economy" [64] (p. 09). The proposed zoning is intended to support housing increments (i.e., special housing areas, single housing areas, mixed housing areas, mixed housing suburban, and terrace housing apartments) and general growth outcomes for Auckland (Figure 5). 


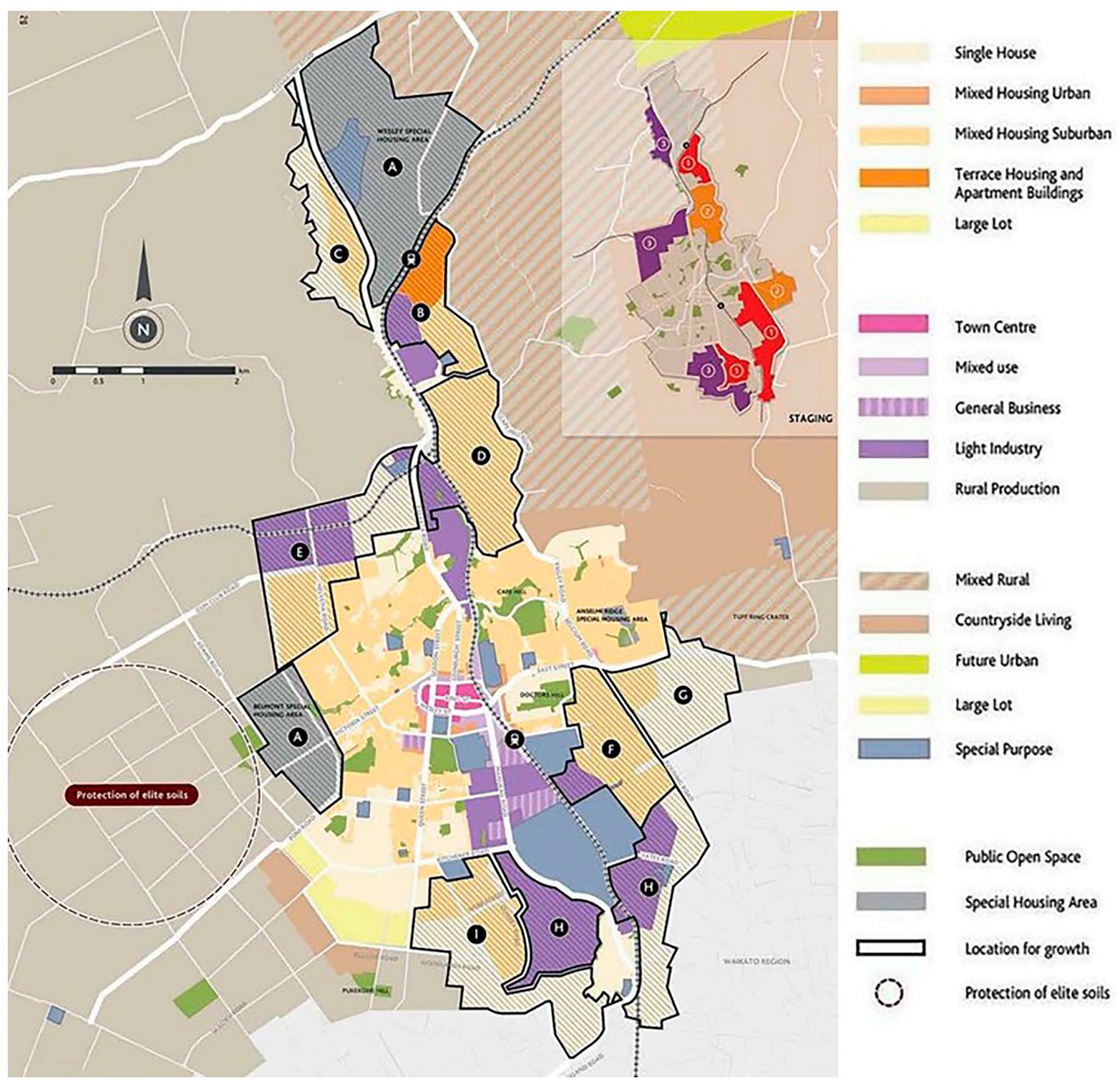

Figure 5. Map of Pukekohe and its proposed land uses (Auckland Council. Pukekohe-Paerata Structure Plan Process. September 2017. Copyright (C Auckland Council, Auckland. New Zealand).

\subsection{Methods and Materials}

The study on which this paper is based included interviews with key stakeholders, site visits, spatial analysis and policy analysis [65]. Twenty-three semi-structured interviews [66] were conducted in 2017 with planners, policy-makers, members of local boards and the Auckland Council, real-estate developers, consultants in urban design, residents and landowners. The stakeholders were selected for their first-hand knowledge of Auckland's urban policy, the area of analysis or their involvement in planning at different levels. The interviews were anonymized so that the respondents could be frank, without fear of professional repercussions.

Site visits were undertaken in the second half of 2017 to observe the peri-urban space subject to housing intensification. They provided visual documentation of and information on the spatial composition of the area, its physical infrastructure, agricultural activities, ongoing urbanization, accessibility and landscape quality. The material gathered enabled spatial analysis and appraisal of the physical landscape and its infrastructure. The information was clustered and collated with policy reports.

It is important to note that for this paper, mainly focused on the analysis of key planning documents [65], only a fraction of the empirical information was used, and it was collated with statistical data from official databases. The documents analysed were the Addendum to the Draft 
Auckland Unitary Plan [67], the Rural Urban Boundary Report [68], the Rural Production report [69], the Capacity for Growth Study [70], the Pukekohe Area Plan [64], the Auckland Council District Plan-Operative Franklin Section [60], the Future Urban Land Supply Strategy [71] and the Auckland Plan [72]. Document analysis also included secondary research, masterplans and urban design proposals, and relevant news articles related to the Pukekohe area (Table 1).

The limitations to this research included the lack of secondary material on Pukekohe from an urban planning perspective. However, this gap was balanced by environmental studies on the agricultural attributes of the area, already menaced by urban expansion. The research was also limited by constraints on accessing a whole range of private properties located at the conurbation between Auckland and Pukekohe. However, these lands are able to be seen from outside as there are no major visual restrictions. Thereby, visual records were made to overcome the lack of access, specifically through photographs that were useful for assessing the spatial characteristics of these lands.

Table 1. Selected documents and main content analysed.

\begin{tabular}{|c|c|}
\hline $\begin{array}{c}\text { Analysed Documents } \\
\text { (Main Policy Reports and Studies) }\end{array}$ & Contents Analysed \\
\hline $\begin{array}{l}\text { (1) Auckland Council District Plan. } \\
\text { Operative Franklin Section, 2000. [60] }\end{array}$ & $\begin{array}{l}\text { Description of the Franklin District regarding } \\
\text { population growth, definition of urban areas, natural } \\
\text { character, and cultural heritage. }\end{array}$ \\
\hline (2) Pukekohe Area Plan. Auckland Council, 2014 [64] & $\begin{array}{l}\text { Description of the Pukekohe plan for urban growth } \\
\text { and its implications for community engagement, } \\
\text { economic growth, transport and natural environment. }\end{array}$ \\
\hline $\begin{array}{l}\text { (3) Addendum to the Draft Auckland Unitary Plan. } \\
\text { Auckland Council (2013a). } 15 \text { March } 2013 \text { [67] }\end{array}$ & $\begin{array}{l}\text { Definition of the Rural-Urban Boundary (RUB) and } \\
\text { associated planning tools for enabling affordable } \\
\text { neighbourhoods. }\end{array}$ \\
\hline $\begin{array}{l}\text { (4) Auckland Unitary Plan - Rural Urban Boundary. } \\
\text { Discussion Paper. Transport Issues. Auckland } \\
\text { Strategy \& Research Department. Auckland Council. } \\
\text { Auckland, New Zealand. [68] }\end{array}$ & $\begin{array}{l}\text { Estimated growth in greenfield areas for investigation. } \\
\text { Location of the RUB and transport infrastructure. }\end{array}$ \\
\hline $\begin{array}{l}\text { (5) Rural production. Comparative analysis. } \\
\text { Greenfield Study Areas. North, North-West and } \\
\text { South Auckland. Primary Focus. Auckland Council, } \\
2013 \text { [69] }\end{array}$ & $\begin{array}{l}\text { Comparative analysis of rural productivity between } \\
\text { selected greenfield areas in northern and } \\
\text { southern Auckland. }\end{array}$ \\
\hline $\begin{array}{l}\text { (6) Capacity for Growth Study } 2013 \text { (Proposed } \\
\text { Auckland Unitary Plan): Results. Auckland Council, } \\
\qquad 2013 \text { [70] }\end{array}$ & $\begin{array}{l}\text { Monitoring of residential, business and rural land } \\
\text { availability. This evaluates the residential capacity, } \\
\text { limitations for residential growth including the main } \\
\text { urban area and also rural towns. }\end{array}$ \\
\hline $\begin{array}{l}\text { (7) Auckland Future Urban Land Supply Strategy. } \\
\text { Auckland Council, } 2017 \text { [71] }\end{array}$ & $\begin{array}{l}\text { This strategy identifies a program to sequence future } \\
\text { urban land over } 30 \text { years and assists with the ongoing } \\
\text { supply of greenfield land for development. }\end{array}$ \\
\hline $\begin{array}{l}\text { (8) The Auckland Plan. Auckland Council, } 2018 . \\
\text { ISBN 978-0-473-21410-4 [72] }\end{array}$ & $\begin{array}{l}\text { The main planning document that provides policy } \\
\text { orientations regarding urban growth, greenfield } \\
\text { developments, rural development, infrastructure, } \\
\text { community engagement, cultural (Maori) } \\
\text { development, recreational and sport policies, } \\
\text { historical heritage, economic growth, environment, } \\
\text { housing and transport. }\end{array}$ \\
\hline
\end{tabular}

\section{Results}

\subsection{Auckland's Urban Sprawl}

Two factors discussed in relation to Auckland's urban sprawl are the increasing population rate and improvements to transport infrastructure $[67,68]$. Recognized as one of the most important 
urbanized areas of the entire Pacific Rim [72], Auckland hosts one-third of New Zealand's population. It is expected that over the next 30 years, Auckland will experience $60 \%$ population growth, increasing from 1.4 million to 2.3 million people, mainly fuelled by natural growth and both internal and overseas migration [61].

During the past 20 years, Auckland has evolved from a traditional agglomeration of suburban districts towards an amalgamated metropolitan entity regulated by a general framework plan, "The Auckland Unitary Plan" [64]. The plan contemplates new zones of expansion beyond consolidated areas, but simultaneously advocates for a "compact city model", indicating that $70 \%$ of future urban development will be placed within urban boundaries [67]. Despite this, projections indicate that future urban expansion will be the main trend and will comprise at least four zones: urban, suburban, peri-urban and ex-urban-configuring a more detailed urban-rural transect and confirming the character of Auckland as a city-region [73]. As previously commented, these categories differ in terms of function, geographical location, spatial configuration and functional relationship with the consolidated city. However, the planning tools that operate in these zones are similar, and as a result the morphological pattern is relatively homogeneous. This sprawling geography is characterized by traditional low-density residential developments that extend over the countryside without acknowledging any functional or spatial variation regarding proximity to the city or the countryside [15]. Ongoing urbanization plans indeed confirm that projected urban forms will be the same all across the peri-urban space (Figure 6). As a control measure, ex-urban development is limited, with the exception of the selected locations of Warkworth in the north and Pukekohe in the south, both surrounded by agricultural and environmental assets [67-69].

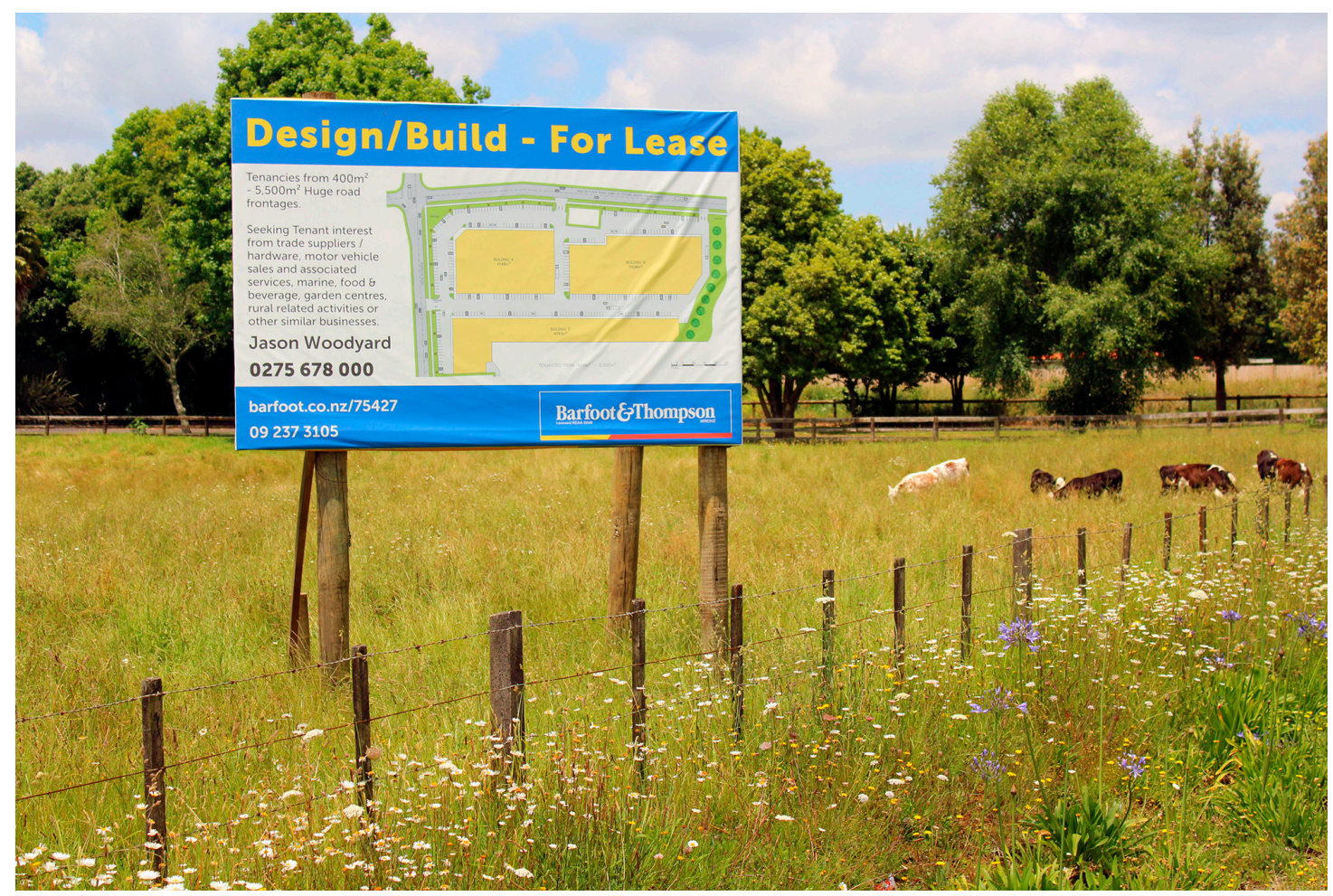

Figure 6. Planned suburbanization between southern Auckland and Pukekohe (Author's photo, November 2017).

The sprawling character of Auckland has gained momentum in light of housing affordability, car dependency, socio-environmental impacts of disperse urbanization and infrastructural needs [74]. Supposedly, urbanization beyond the consolidated area should improve housing affordability. However, Auckland does not describe a typical economic geography where outer lands become automatically cheaper. The factors that distort the typical reduction of land prices closer to the 
countryside relate to a series of natural amenities (e.g., beaches, forests and parks) that influence land prices. Additionally, urban limits and other growth restrictions do not include methods of land-value capture for regressive investment [3]. This is more critical considering that the meaning of "affordability" is still under debate in current New Zealand legislation [12]. Indeed, the Auckland Plan states that "there is no agreed definition or measure of 'affordable' or 'unaffordable' housing" [72] (p. 269), but nevertheless indicates that housing affordability is a priority considering "the housing crisis" [72] (p. 269). It is well-known that Auckland has the highest price-to-rent ratio and the second highest price-to-income ratio of the OECD countries [75]. Thus, the release of land in the peri-urban space-particularly within the so-called "Rural-Urban Boundary" (RUB)—would ensure enough development capacity, as the value of land within the limits is around nine times higher than prices just outside them [12,73]. Despite their impacts, the determinants that explain Auckland's sprawl are seen simply as factors that cannot be controlled by planning policies, and as natural constraints of neoliberal regimes that cannot harmonize economic growth with environmental protection [76].

\subsection{Auckland's Peri-Urban Space, the RUB and Their Ambiguities}

Along with other Australasian cities and as previously discussed, Auckland's peri-urban space is defined as the interface between the city and the countryside. However, this is ambiguous considering that the urban-rural interface takes varied forms in terms of land uses and morphological aspects, making it difficult to identify where this peri-urban space is located, or where the city ends and the countryside starts [77]. In the case of Auckland, the "Rural-Urban Boundary" (RUB) is a planning scheme aimed at fixing the geography of this urban-rural interface, establishing future areas for expansion and restrictions on growth. More specifically, the RUB is a planning tool-part of the Auckland Unitary Plan - that defines the extent of urban development to 2041, and areas to be kept as rural. Its purpose is to achieve efficient urban development and the conservation of the countryside and its productive rural soils. The RUB also defines the available space for the sequenced provision of infrastructure to support growth and urban development in existing urban and greenfield areas [68].

The RUB replaced the "Metropolitan Urban Limit" (MUL) in 2010. The abolition of the MUL was due to a series of land-price distortions triggered by zoning decisions linked to the location of the MUL. As with most urban limits, the MUL operates via the definition of a boundary that determines the inclusion of new rural lands for urbanization. This is common in cities where traffic externalities are unpriced. In the case of Auckland, land immediately to the inward side of the boundary was valued at a higher rate per hectare than land immediately on the outward side of the boundary. Furthermore, the MUL was considered inappropriate, as it was a response to an idealized monocentric city model that does not reflect Auckland's morphological and functional characteristics. Auckland is increasingly described as polycentric, and thus not suitable for the simple application of growth restrictions such as the MUL [3]. Therefore, the RUB emerged to define a hybrid (urban-rural) zone complemented by infrastructure and services [3]. Nevertheless, this replacement did not address the planning ambiguities previously defined by the MUL, and opened up new uncertainties related to its still prescriptive character.

The Auckland Plan clearly indicates that-through proposed growth zones-the RUB provides flexible conditions to allow up to $40 \%$ of new homes to be built outside the urban limit in well-planned greenfields to ensure land availability for the next 30 years [68]. This approach is designed to provide certainty to communities, landowners, infrastructure providers and developers on where Auckland will experience the most significant changes. For the Auckland Unitary Plan, the RUB is a geographical space "that will define the maximum extent of urban development to 2040 in the form of permanent rural-urban interface" [68] (p. 07), and which embraces part of the metropolitan area, rural-coastal villages, and the satellite towns of Warkworth in the north and Pukekohe in the south.

Depending on the location, the RUB can be a simple line delimiting and consolidating areas and their expansion, or it can circumscribe an entire new area for urban development. The new areas can be adjacent to current consolidated zones (i.e., continuous growth), or be spatially separated from the 
city (i.e., discontinuous growth). Figure 7 shows how the RUB in the north delimits growth areas in the form of a line, but in Warkworth, for instance, it circumscribes almost the entire town. The same situation applies for the west, while in the south it defines the expansion areas for Papakura and Paerata, and circumscribes the entire town of Pukekohe and its surroundings (Figure 7).

The RUB paints an interesting picture, considering that previous tools for urban containment have usually used two main strategies, greenbelts and urban growth boundaries [78], both characterized by a continuous shape without gaps for urban expansion. However, the RUB offers a different approach as a discontinuous spatial demarcation that at different points appears open or closed, depending on the geographical and functional purposes.

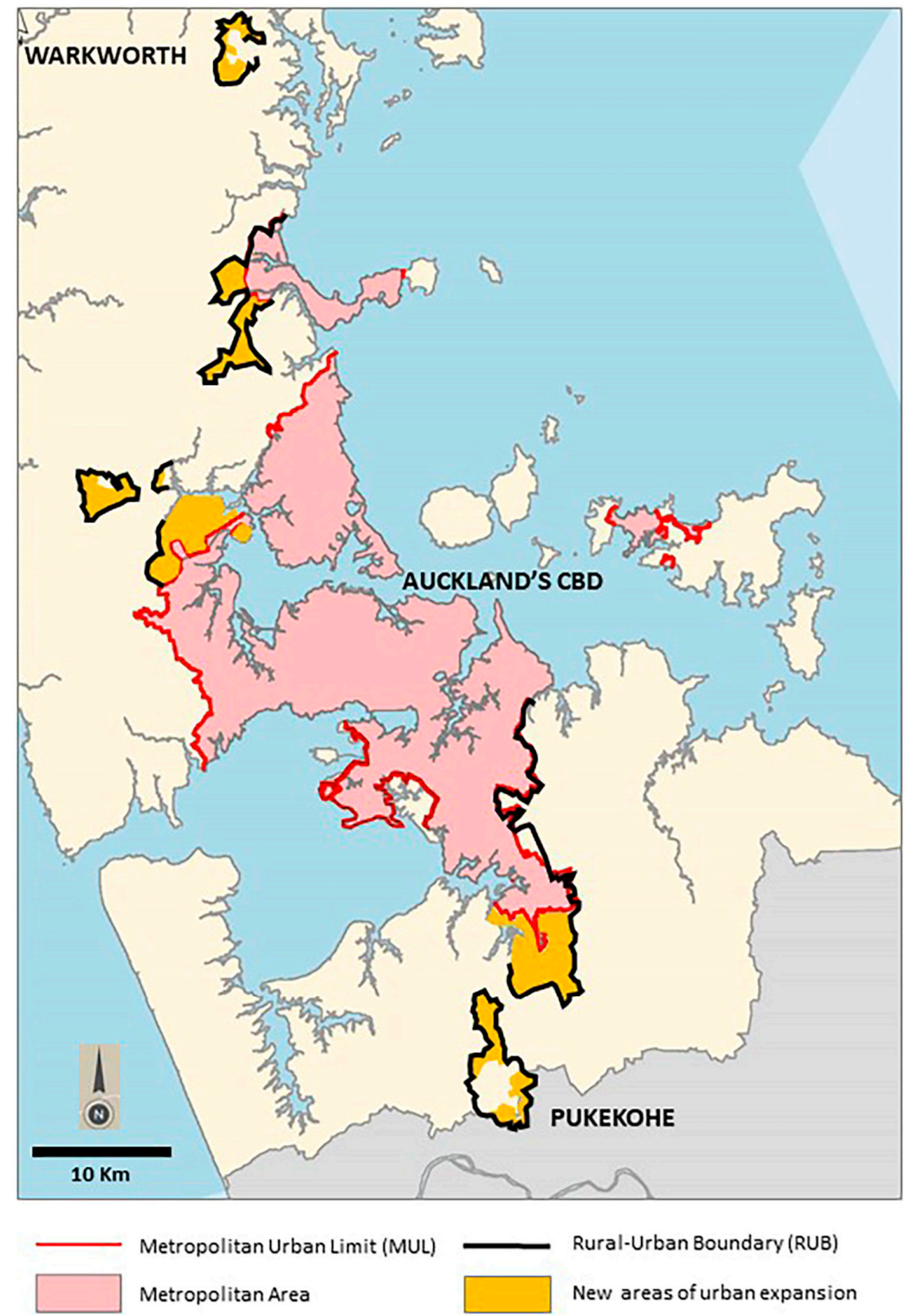

Figure 7. Map of the metropolitan area of Auckland showing the MUL, the RUB and areas of expansion (Author's map).

Another ambiguity relates to indications that the RUB is encouraging further growth in existing urban areas to protect the rural space. Nevertheless, the documentation also states that greenfield 
areas for investigation will be delineated by the RUB and thus urban boundaries can be reshaped [24]. Furthermore, the RUB indicates that natural features will be considered only to provide well-defined physical boundaries, mainly highlighting the spatial values of the peri-urban landscape but clearly reducing its ecological character to elements for marketable purposes. This conceptual reduction is relevant as it obscures the environmental damage caused by urbanization of fertile rural lands [13,14]. The Auckland Plan presents further planning ambiguities when it states that urban expansion into rural villages must "avoid urbanisation of highly productive farmland and versatile soils where possible ..." [72] (p. 230), but simultaneously considers re-zoning rural lands for future urbanization "to allow rural activities to continue until urban development can take place" [72] (p. 4). This explicitly determines the temporary character of rural and environmental assets as subject to suburbanization over time. What is more, such ambiguities are paradoxically clear in terms of benefits to individual landowners as they define direct transferences of wealth under discretional decision-making. Once rural lands are transformed into urban, the plan indicates that their value will increase with the concurrent transference of wealth to the landowner (windfall gain as an outcome of rezoning decisions). By way of compensation, the plan also proposes that the Council should receive a proportion of this land-value capture to re-invest in infrastructure, public works, affordable housing or further growth [72]. However, the legal strength of this mechanism is under revision, as the Local Government Act first has to be changed to ensure the Council's power to implement this levy [71].

Finally, a further structural ambiguity is an institutional framework that simultaneously controls urban development and environmental preservation: the Ministry for the Environment (MfE). In New Zealand, urban planning and farming protection both fall under the jurisprudence of the MfE. On the one hand, this representation exerts a strong influence in formulating policy statements, strategies and action plans for the protection of versatile lands that are considered resources of national importance. Fertile soils represent a small percentage of New Zealand's land area and are considered as a finite and ever-decreasing resource in high demand, particularly in relation to land-use activities that are largely irreversible. It is not unusual for environmentalists to use the MfE as a platform to advocate for a national policy on strategic land resources, including the creation of "National Food Security Zones" of high-class land protected for exclusively soil-based food production. They argue that this framework would give the land the same status and protection as conservation land. In a similar vein, Horticulture [13] proposed a "Domestic Food Security Policy" to ensure the continued sustainable local production of fresh food for the nation [13]. On the other hand, the MfE also drafts policies and planning tools to implement urbanization using well-defined planning and urban design principles. In 2002, for instance, the MfE published the report "People + Places + Spaces: A Design Guide for Urban New Zealand" as the first comprehensive attempt to define urban design and its implications. This report aimed to support high-quality planning and urban design outcomes [79] and was later reinforced by the creation of the so-called "New Zealand Urban Design Protocol" (2005) [80]. Here, seven essential design qualities (known as the "seven Cs": context, character, choice, connections, creativity, custodianship, collaboration) inform the design process and ensure the implementation of good urban design projects. However, these reports do not acknowledge the rural character of the country-particularly evident in the peri-urban areas-and sustain a relatively standardized approach seen in other latitudes characterized by heavily urbanized regions, such as in the UK or the Netherlands. The reports are all about what to do rather than what to preserve, and do not provide clear clues on how to incorporate the evident rural identity of New Zealand into planning and urban design theory and practice.

\section{Discussion}

\section{The Expansion to Pukekohe}

As mentioned, Pukekohe is a satellite town located in the Franklin District, $50 \mathrm{~km}$ from the Auckland's CBD. The area is characterized by its rural landscapes, which are already marked for 
urban expansion. A critical zone is the area between southern Auckland and Pukekohe, known as Paerata and Drury, which is intended for housing intensification [63]. This area is a typical example of the New Zealand countryside, and is recognized for its frost-free climate and highly productive rural soils (Figure 8) [13]. This area comprises around $86 \%$ Class 1 soils, is a powerhouse of outdoor vegetable production [14] and is seen as a significant source of economic activity and employment growth [60]. In rural studies, this area is identified as one to be protected from urban encroachment, as it provides food for the entire region [69]. It is mainly the southern space composed of Karaka, Paerata and Pukekohe that contributes, with around $60 \%$ of the overall turnover per hectare dominated by dairying, livestock grazing, vegetable growing and cropping. Its Class I, II and III soils make the Franklin District very competitive in terms of local supply and exports to other regions, and it contributes $10.6 \%$ of the Auckland region's GDP [69]. As stated in the Franklin Plan, the Pukekohe area "... has some of the most productive soils in New Zealand and has long been associated with market gardening" [60] (p. 1).

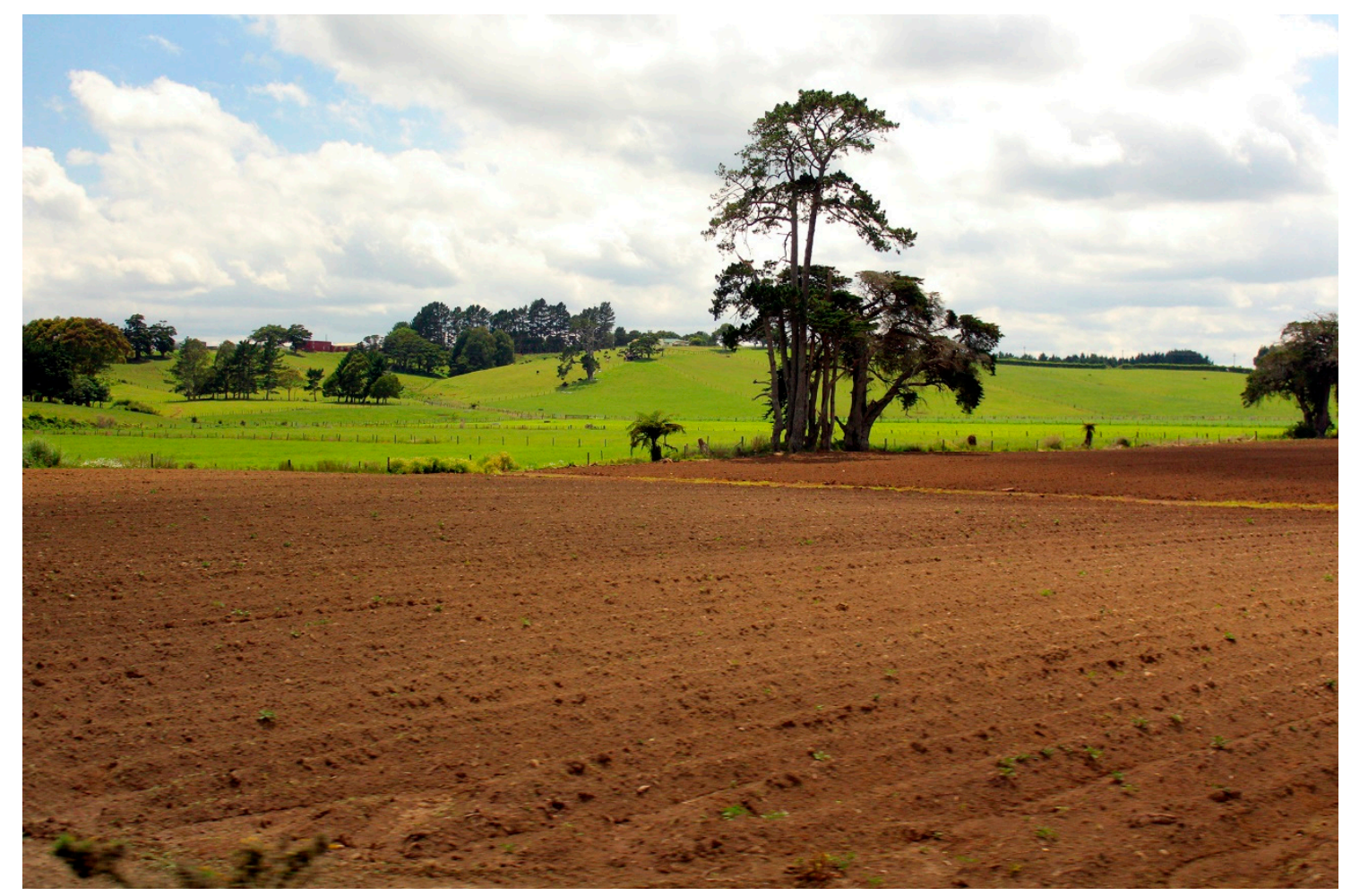

Figure 8. Agricultural lands between Auckland and Pukekohe (Author's photo, November 2017).

There is abundant evidence to confirm that Pukekohe's surroundings have some of New Zealand's most productive soils due to the inherently fertile qualities of the volcanically derived soil composition [13]. Its frost-free status provides competitive advantages, as outdoor crops can be grown all year round, without succumbing to winter frosts as in most other regions across New Zealand. It is not uncommon for local farmers to produce three crops of potatoes on the same piece of ground over a 14-month period [14]. Qualitative studies indicate that local farmers perceive Pukekohe as a land reserve for the production of healthy food, and handily located for delivery to nearby city markets [14]. Associated benefits are greater profitability linked to reduced freight costs and shorter distances for food to travel from farm to plate [81]. However, the versatile soils of Pukekohe are predominantly located on future urban zones that will clearly diminish their productivity, with impacts on the wider economy. Pukekohe's farmers are well placed to respond to local, national and even international consumption demands [82]. However, these needs exist alongside an equally important need to release more land for housing. Several reports have advised that starting from the 1940s, thousands of 
"acres" of highly productive land within Auckland have gone out of production as a result of urban growth [83]. This is increasingly critical in light of financial constraints, but also to the continuity of farming activity by new generations. Younger people are particularly reluctant to enter into family farming businesses and therefore selling the land to a developer becomes appealing when property and land prices are increasing. This is certainly the case in Pukekohe, which is marked to receive a considerable portion of housing development due to a demand for housing that exceeds supply, and consolidated by a narrative of what has been described as a "housing crisis" [83].

On a similar basis, Pukekohe and its surroundings have been the subject of environmental analysis, specifically related to the series of ecosystem services linked to the rural hinterland. In the Pukekohe area alone, at least nine ecosystem services have been detected that are considered essential for the entire region's environment. These ecosystem services include: (1) fishing areas, (2) freshwater streams, (3) air channels, (4) medicinal plants and genetic and biochemical resources, (5) regulation of local climate, (6) high-quality soils and nutrients, (7) pollination areas, and (8) natural hazard mitigation. Additionally, the area is recognized as significant in terms of cultural services such as recreation and ecotourism, education and, finally, cultivation of spiritual values [84] as the natural landscape contains multiple Maori cultural elements [85]. However, these ecosystem services are under threat, as if land is converted for housing it will no longer produce agricultural products and trigger irreversible changes in the functional performance of the natural environment [86].

More specifically, and in terms of urbanization, it is projected that 400,000 additional households should be completed by 2040 , and that $40 \%$ will be located outside metropolitan boundaries and distributed around Pukekohe, and in rural coastal towns, greenfield areas and rural villages [24]. It is intended that Pukekohe's surroundings will host around 50,000 new people, up to 55,000 dwellings and 35,000 jobs [68]. The areas for urbanization are Paerata North, Pukekohe North East, Pukekohe West, Pukekohe South and Drury, which are all marked for housing intensification [68]. Prioritized scenarios are defined around existing transportation corridors and hubs—compared to other greenfields-as they have significant implications for public expenditure.

Following the adoption of the Auckland Plan, Pukekohe was zoned as "future urban". Subsequently, further policy documents signalled the development of future urban areas across the Auckland region and determined part of Pukekohe as available for urban development, with remaining areas coming on stream from 2023 [73]. An area is considered "development ready" if bulk infrastructure is available and if quality urban outcomes, as outlined in the Auckland Plan and the Unitary Plan, can be achieved [64]. This is the case for Pukekohe, as it has enough available services and planned improvements to transport to justify its re-zoning. The anticipated dwelling capacity for Pukekohe is approximately 14,350 [64,71], to be located within the bounds of the RUB. The Future Urban Land Supply Strategy also identifies the conurbation zone as suitable for expansion, particularly the rural area between Pukekohe's existing urban area and the RUB.

As an additional pressure, maintaining rural properties is increasingly expensive, partly because of the high-costs associated with land ownership, and also the fact that high land-values create the need to produce goods more efficiently, sell into high-value market niches or increase productivity per hectare [60]. As an alternative, cross-subsidizing rural production costs with off-farm income emerges as an option for achieving commercial rates of return. Nevertheless, this triggers strong incentives for land subdivision for urban purposes, with various environmental impacts associated with land fragmentation [69]. The consolidation of Pukekohe as a satellite town of Auckland will encourage land subdivision of the rural surroundings, fragmentation of productive land, commodification of rural landscapes, and raise governance issues related to cross-boundary relations with neighbouring regions [68]. It is expected that the area will finally become seen as a desirable place to live, in part stimulated by transport improvements. At least this is the predominant narrative in real estate promotions. However, planning ambiguities encourage urban sprawl and consolidate suburbia, with a clear absence of rural identity beyond the mere fact of being physically close to the countryside. 
These results support previous studies on the extent to which planning policies are inefficient in restraining urban sprawl, or at least in promoting alternative solutions to suburbanization. They conclude that policy-based approaches are insufficient for urban containment, and can even promote dispersed suburbanization through important omissions that obscure the role of developers or rural landowners and their vested interest in real estate projects, or simply because planning policies are not linked to findings from environmental sciences or rural studies [86]. A similar conclusion has been reached by studies conducted in China, where planning is strongly correlated with urban sprawl, concluding that urban sprawl is a kind of "planned sprawl" for large Chinese cities [31].

\section{Conclusions}

Urban sprawl appears to be an unexpected outcome of planning policies and regimes of control. The case of Auckland demonstrates that ambiguous definitions, flexible interpretation of regulations and weak rural opposition contribute to dispersed suburbanization of rural lands. More specifically, this is partly explained by the lack of consensus on what urban sprawl is, what it looks like, and its major impacts, and also the limited scope of planning instruments in balancing urban and rural assets. It is difficult for planning rationales to incorporate the environmental values of rural lands and mitigate the impacts of urban sprawl. This is the result of conceptual reductions and the ambiguity of guides to action. It is also clear that planning frameworks fail in characterizing the urban-rural interface as a landscape composed of both urban and rural assets that can be integrated. This is significant, considering that a more rural-based approach to planning can inspire alternative solutions for the urban-rural interface.

In the case of Auckland and its extension to Pukekohe, several studies have highlighted the rural and ecological dimension of the peri-urban boundary. However, this dimension is not evident in planning instruments and rural areas are clearly disadvantaged by the urban determinants of urban sprawl, including the well-established asymmetry between urban and rural policies. This is interesting considering that rural preservation and urbanization processes both fall under the same umbrella representation (the MfE), where there is a clear lack of internal consistency and cross-sectorial coordination.

The findings of this paper contribute at both theoretical and practical levels. At a conceptual level, it is possible to argue that, despite policy attempts at managing urban growth, urban sprawl emerges as an outcome of less-controlled processes in planning occurring as a series of policy absences and ambiguities. In part, this is due to the fact that planning has traditionally been defined as a prescriptive discipline that indicates what "not" to do rather than what to do, leaving space for the piecemeal configuration of a fragmented peri-urban landscape as a simile for its suburban counterpart. It is interesting to consider that the production of peri-urban space is the result of different project-based initiatives, that again find their references in traditional suburbia rather than the outcome of policy-based frameworks supported by principles of environmental and rural sustainability. This clearly opens up tensions between "command and control" processes versus the creation of flexible scenarios for more strategic and adaptable decision-making.

In practical terms, the findings suggest that, despite the inertia of traditional suburbia in defining the peri-urban landscape, the presence of rural assets can inspire new practices in planning and cognate disciplines involved in the production of the living space (e.g., landscape planning and urban design). Clearly, the planning and design of the peri-urban space can be complemented with values and practices from political ecology, ecosystem services, urban agriculture, natural capital, green infrastructure and landscape design, for instance, and go beyond mere trade-offs subdued to the housing shortage. Understanding the peri-urban landscape as a platform for planning experimentation can shift the focus from the competing values of farming productivity, natural processes and rural character versus housing intensification, to finally create planning for ecological modernization (the "urbanized countryside"). If its hybrid urban-rural character defines the nature of the peri-urban context, why then does this not penetrate the way neighbourhoods and buildings are conceived? 
Looking at the future of the peri-urban space, it is expected that new conceptual gateways to planning and the elimination of policy barriers to implementing green infrastructure will help in addressing impacts of urban sprawl from its rural dimension, and eventually in exploring its autonomy as a distinctive geography that deserves planning and design approaches in its own right.

Funding: This research was funded by the School of Architecture and Planning, University of Auckland. School PBRF allocation R2. Project number A1714.

Acknowledgments: The author is grateful for the research sponsorship, and to the Auckland Council and Franklin Council for the provision of valuable insights and information about Auckland's urban development. The author gratefully acknowledges the critical review by reviewers on an earlier version of the manuscript.

Conflicts of Interest: The author declares no conflict of interest.

\section{References}

1. Barnes, K.B.; Morgan, J., III; Roberge, M.; Lowe, S. Sprawl Development: Its Patterns, Consequences, and Measurement; Towson University: Towson, MD, USA, 2001; pp. 1-24.

2. Gallent, N.; Shaw, D. Spatial Planning, Area Action Plans and the Rural-Urban Fringe. J. Environ. Plan. Manag. 2007, 50, 617-638. [CrossRef]

3. Grimes, A.; Liang, Y. Spatial Determinants of Land Prices: Does Auckland's Metropolitan Urban Limit Have an Effect? Appl. Spat. Anal. 2009, 2, 23-45. [CrossRef]

4. Girling, C. Smart Growth meets low impact development: A case study of UniverCity, Vancouver, Canada. J. Urban. 2010, 3, 69-93. [CrossRef]

5. Haarhoff, E.; Beattie, L.; Dupuis, A. Does higher density housing enhance liveability? Case studies of housing intensification in Auckland. Cogent Soc. Sci. 2016, 2, 1-16. [CrossRef]

6. Rice, L. Retrofitting suburbia: Is the compact city feasible? Urban Des. Plan. 2010, 163, 193-204. [CrossRef]

7. Thomson, G.; Newton, P.; Newman, P. Urban regeneration and urban fabrics in Australian cities. J. Urban Regener. Renew. 2017, 10, 169-190.

8. Mees, P. How dense are we? Another look at urban density and transport patterns in Australia, Canada and the USA. Road Transp. Res. 2009, 18, 58-67.

9. Willing, R.; Pojani, D. Is the suburban dream still alive in Australia? Evidence from Brisbane. Aust. Plan. 2017, 54, 67-79. [CrossRef]

10. McArthur, J. Auckland: Rescaled governance and post-suburban politics. Cities 2017, 64, 79-87. [CrossRef]

11. Mattingly, K.; Morrissey, J. Housing and transport expenditure: Socio-spatial indicators of affordability in Auckland. Cities 2014, 38, 69-83. [CrossRef]

12. Brebner, M. Auckland's housing affordability problem. N. Z. J. Environ. Law 2014, 18, 207-239.

13. Curran-Cournane, F.; Vaughan, M.; Memon, A.; Fredrickson, C. Trade-offs between high class land and development: Recent and future pressures on Auckland's valuable soil resources. Land Use Policy 2014, 39, 146-154. [CrossRef]

14. Curran-Cournane, F.; Cain, T.; Greenhalgh, S.; Samarsinghe, O. Attitudes of a farming community towards urban growth and rural fragmentation-An Auckland case study. Land Use Policy 2016, 58, 241-250. [CrossRef]

15. Ghosh, S.; Vale, R. Typologies and basic descriptors of New Zealand residential urban forms. J. Urban Des. 2009, 14, 507-536. [CrossRef]

16. Gillham, O. What is Sprawl? The Limitless City. A Primer on the Urban Sprawl Debate; Island Press: Washington, DC, USA, 2002.

17. Hess, G.; Daley, S.; Dennison, B.; Lubkin, S.; McGuinn, R.; Morin, V.; Potter, K.; Savage, R.; Shelton, W.; Snow, C.; et al. Just What is Sprawl, Anyway? Carol. Plan. 2001, 26, 11-26.

18. Wolman, H.; Galster, G.; Hanson, R.; Ratcliffe, M.; Furdell, K.; Sarzynski, A. The fundamental challenge in measuring sprawl: Which land should be considered? Prof. Geogr. 2005, 57, 94-105.

19. Soule, D. Urban Sprawl: A Comprehensive Reference Guide; Greenwood Publishing Group, Inc.: Praeger, CT, USA, 2006.

20. Ekers, M.; Hamel, P.; Keil, R. Governing suburbia: Modalities and mechanisms of suburban governance. Reg. Stud. 2012, 46, 405-422. [CrossRef] 
21. Torrens, P. Simulating Sprawl. Ann. Assoc. Am. Geogr. 2006, 96, 248-275. [CrossRef]

22. Jaret, C.; Ghadge, R.; Reid, L.W.; Adelman, R. The Measurement of Suburban Sprawl: An Evaluation. City Community 2009, 8, 65-84. [CrossRef]

23. Romero, H.; Órdenes, F. Emerging Urbanization in the Southern Andes. Environmental Impacts of Urban Sprawl in Santiago de Chile on the Andes Piedmont. Mt. Res. Dev. 2004, 24, 197-201. [CrossRef]

24. Nelson, A. Comparing States with and Without Growth Management Analysis Based on Indicators with Policy Implications. Land Use Policy 1999, 16, 121-127. [CrossRef]

25. Sieverts, T. Cities without Cities: An Interpretation of the Zwischenstadt; Spon Press: London, UK; New York, NY, USA, 2003.

26. Tacoli, C. Rural-Urban Interactions: A Guide to the Literature. Environ. Urban. 1998, 10, 147-166. [CrossRef]

27. Hamel, P.; Keil, R. Suburban Governance: A Global View; University of Toronto Press: Toronto, ON, Canada, 2015.

28. Galster, G.; Hanson, R.; Ratcliffe, M.; Wolman, H.; Coleman, S.; Freihage, J. Wrestling Sprawl to the Ground: Defining and Measuring an Elusive Concept. Hous. Policy Debate 2001, 12, 681-717. [CrossRef]

29. Ravetz, J.; Loibl, W. The dynamics of the peri-urban: Global change and regional response. In Peri-Urbanisation in Europe: Towards European Policies to Sustain Urban-Rural Futures; Synthesis Report; PLUREL [Sixth Framework Programme]; Piorr, A., Ravetz, J., Tosics, I., Eds.; Forest \& Landscape, University of Copenhagen: Frederiksberg, Denmark, 2011.

30. García-Ayllón, S. Rapid development as a factor of imbalance in urban growth of cities in Latin America: A perspective based on territorial indicators. Habitat Int. 2016, 58, 127-142. [CrossRef]

31. Tian, L.; Li, Y.; Yan, Y.; Wang, B. Measuring urban sprawl and exploring the role planning plays: A Shanghai case study. Land Use Policy 2017, 67, 426-435. [CrossRef]

32. Garcia-Ayllon, S. Urban transformations as indicators of economic change in post-communist Eastern Europe: Territorial diagnosis through five case studies. Habitat Int. 2018, 71, 29-37. [CrossRef]

33. Phelps, N.; Wood, A. The New Post-Suburban Politics? Urban Stud. 2011, 48, 2591-2610. [CrossRef]

34. Kloosterman, R.; Lambregts, B. Clustering of Economic Activities in Polycentric Urban Regions: The Case of the Randstad. Urban Stud. 2001, 38, 717-732. [CrossRef]

35. Roe, P.G.; Saglie, I.L. Minicities in suburbia. A model for urban sustainability? FORMakademisk 2011, 4, 38-58.

36. Phelps, N. An Anatomy of Sprawl: Planning and Politics in Britain; Routledge: London, UK, 2012.

37. Forester, J. Planning in the Face of Conflict: The Surprising Possibilities of Facilitative Leadership; A Planners Press Book; Routledge: London, UK; New York, NY, USA, 2017.

38. Hebbert, M. Urban Sprawl and Urban Planning in Japan. Town Plan. Rev. 1986, 57, 141-158. [CrossRef]

39. Oueslati, W.; Alvanides, S.; Garrod, G. Determinants of urban sprawl in European cities. Urban Stud. 2015, 52, 1594-1614. [CrossRef] [PubMed]

40. Qian, H.; Wong, C. Master Planning under Urban-Rural Integration: The case of Nanjing, China. Urban Policy Res. 2012, 30, 403-421. [CrossRef]

41. Zhang, R.; Pu, L.; Zhu, M. Impacts of transportation arteries on land use patterns in urban-rural fringe: A comparative gradient analysis of Qixia District, Nanjing City, China. Chin. Geogr. Sci. 2013, 23, 378-388. [CrossRef]

42. Kassa, F. Conurbation and Urban Sprawl in Africa: The case of the City of Addis Ababa. Ghana J. Geogr. 2013, 5, 73-89.

43. Garcia, E.J.; Vale, B. Unravelling Sustainability and Resilience in the Built Environment; Routledge: London, UK, 2017.

44. Ige, J.O.; Atanda, T.A. Urban Vacant Land and Spatial Chaos in Ogbomoso North Local Government, Oyo State, Nigeria. Glob. J. Hum. Soc. Sci. Environ. Sci. Disaster Manag. 2013, 13, 28-36.

45. De Zeeuw, H.; Gündel, S.; Waibel, H. The integration of agriculture in urban policies. In Growing Cities, Growing Food: Urban Agriculture on the Policy Agenda; Deutsche Stiftung fur internationale Entwicklung (DSE): Feldafing, Germany, 2000; pp. 161-180.

46. Brenner, N.; Elden, S. Henri Lefebvre on State, Space, Territory. Int. Political Sociol. 2009, 3, $353-377$. [CrossRef]

47. Phelps, N.A.; Silva, C. Mind the gaps! A research agenda for urban interstices. Urban Stud. 2018, 55, 1203-1222. [CrossRef] 
48. Foo, K.; Martin, D.; Wool, C.; Polsky, C. The production of urban vacant land: Relational placemaking in Boston, MA neighborhoods. Cities 2013, 35, 156-163. [CrossRef]

49. Caspersen, O.; Konijnendijk, C.; Olafsson, A. Green Space Planning and Land Use: An Assessment of Urban Regional and Green Structure Planning in Greater Copenhagen. Dan. J. Geogr. 2006, 106, 7-20. [CrossRef]

50. Gravsholt Busk, A.; Kristensen, S.; Praestholm, S.; Reenberg, A.; Primdahl, J. Land System Changes in the context of urbanization: Examples from the Peri-Urban Area of Greater Copenhagen. Dan. J. Geogr. 2006, 106, 21-34.

51. Salet, W.; Woltjer, J. New concepts of strategic spatial planning dilemmas in the Dutch Randstad region. Int. J. Public Sect. Manag. 2009, 22, 235-248. [CrossRef]

52. Van Oort, F.; Burger, M.; Raspe, O. On the Economic Foundation of the Urban Network Paradigm: Spatial Integration, Functional Integration and Economic Complementarities within the Dutch Randstad. Urban Stud. 2010, 47, 725-748. [CrossRef]

53. Fazal, S.; Geertman, S.; Toppen, F. Interpretation of Trends in Land Trasformation-A case of Green Heart Region (The Netherlands). Nat. Resour. 2012, 3, 107-117.

54. Faludi, A. The Netherlands: A Country with a Soft Spot for Planning. Comparative Planning Cultures; Routledge: Vienna, Austria, 2005.

55. Auckland One of the Most Liveable Cities. Available online: https://www.nzherald.co.nz/business/news / article.cfm?c_id=3\&objectid=11696591 (accessed on 8 August 2018).

56. Who Says Auckland is 'the Eighth Most Liveable City in the World?'. Available online: https:/ / www.stuff. co.nz/auckland/102180940/who-says-auckland-is-the-eighth-most-liveable-city-in-the-world (accessed on 8 August 2018).

57. Gibson, A. Auckland Has the Fifth Least-Affordable Houses in the World. Available online: http:// www. nzherald.co.nz/business/news/article.cfm?c_id=3\&objectid=11579043 (accessed on 8 August 2018).

58. The Automobile Association (AA) of New Zealand. Auckland Congestion Report 2017. March 2018. Available online: https://www.aa.co.nz/assets/Congestion-Monitoring-Collateral/ AA-Auckland-Congestion-Report-2017-FINAL.pdf?m=1522882971\%22\%20class=\%22type: $\backslash$ protect $\backslash$ T1 $\backslash$ textbraceleftpdf \protect $\backslash \mathrm{T} 1 \backslash$ textbraceright $\% 20$ size: $\backslash$ protect $\backslash \mathrm{T} 1 \backslash$ textbraceleft704\%20KB $\backslash$ protect $\backslash \mathrm{T} 1 \backslash$ textbraceright\%20file (accessed on 21 December 2018).

59. Murphy, L. Third-wave gentrification in New Zealand: The case of Auckland. Urban Stud. 2008, 45, 2521-2540. [CrossRef]

60. Auckland Council District Plan. Operative Franklin Section 2000. Available online: https: / / www.aucklandcouncil.govt.nz/plans-projects-policies-reports-bylaws/our-plans-strategies / districtand-regional-plans/district-plans/franklin-district-plan/Pages/default.aspx (accessed on 8 August 2018).

61. Statistics New Zealand. Populations Projection Overview. Available online: http://www.stats.govt.nz/ browse_for_stats/population/estimates_and_projections/projections-overview/subnat-pop-proj.aspx (accessed on 8 August 2018).

62. Imran, M.; Pearce, J. Auckland's first spatial plan: Ambitious aspirations or furthering the status quo? Cities 2015, 45, 18-28. [CrossRef]

63. Memon, A.; Davies, T.G.; Fookes, T. Institutional arrangements for metropolitan government and strategic planning in Auckland. N. Z. Geogr. 2007, 63, 43-54. [CrossRef]

64. Auckland Council. Pukekohe Area Plan, 2014. Available online: https://www.aucklandcouncil.govt. nz/about-auckland-council/how-auckland-council-works/local-boards/all-local-boards/franklin-localboard/Pages / franklin-plans-agreements-reports.aspx (accessed on 7 August 2018).

65. Bowen, G.A. Document analysis as a qualitative research method. Qual. Res. J. 2009, 9, 27-40. [CrossRef]

66. Barriball, K.; While, A. Collecting data using a semi-structured interview: A. discussion paper. J. Adv. Nurs. 1994, 19, 328-335. [CrossRef]

67. Auckland Council. Addendum to the Draft Auckland Unitary Plan. 15 March 2013. Available online: http:/ / www.aucklandcouncil.govt.nz/EN/planspoliciesprojects/plansstrategies/unitaryplan/

Documents/unitaryplanaddendumrub.pdf (accessed on 5 August 2018).

68. Arbury, J. Auckland Unitary Plan-Rural Urban Boundary. Discussion Paper. Transport Issues; Auckland Strategy \& Research Department, Auckland Council: Auckland, New Zealand, 2012.

69. Powell, D.; Lambert, A. Rural Production. Comparative Analysis. Greenfield Study Areas. North, North-West and South Auckland. Primary Focus; The Auckland Council: Auckland, New Zealand, 2013. 
70. Auckland Council. Capacity for Growth Study 2013 (Proposed Auckland Unitary Plan): Results. 2013. Available online: http:/ /www.aucklandcouncil.govt.nz/EN/planspoliciesprojects/reports/ technicalpublications/Documents/tr2014010capacityforgrowthstudy2013results.pdf (accessed on 10 July 2017).

71. Auckland Council. Auckland Future Urban Land Supply Strategy. Available online: https: / / www.aucklandcouncil.govt.nz/plans-projects-policies-reports-bylaws/our-plans-strategies/topicbased-plans-strategies/housing-plans/Documents / future-urban-land-supply-strategy.pdf (accessed on 8 August 2018).

72. Auckland Council. The Auckland Plan; Auckland Council: Auckland, New Zealand, 2018; ISBN 978-0-473-21410-4.

73. Bradbury, M.; Bogunovich, D. Resilient Sprawl: An Alternative Auckland Plan. In Proceedings of the Governing City Futures Conference, Sydney, Australia, 16-17 August 2013.

74. Chambers, P.; Walters, A. Auckland Council: Creating a transformational shift towards a sustainable eco-economy. In The Economy of Green Cities; Simpson, R., Zimmermann, M., Eds.; Springer: Amsterdam, The Netherlands, 2013; pp. 381-390.

75. OECD. Economic Outlook, Chapter 1: General Assessment of the Macroeconomic Situation. 2014. Available online: https://www.oecd.org/eco/outlook/Economic-Outlook-97-General-assessment.pdf (accessed on 8 August 2018).

76. Gunder, M. Fantasy in planning organisations and their agency: The promise of being at home in the world. Urban Policy Res. 2014, 32, 1-15. [CrossRef]

77. Kennedy, M.; Butt, A.; Amati, M. Conflict and Change in Australia's Peri-Urban Landscapes; Routledg: London, UK, 2016.

78. Gennaio, M.P.; Hersperger, A.M.; Bürgi, M. Containing urban sprawl-Evaluating effectiveness of urban growth boundaries set by the Swiss Land Use Plan. Land Use Policy 2009, 26, 224-232. [CrossRef]

79. Ministry for the Environment. People + Places + Spaces: A Design Guide for Urban Bew Zealand; ME Number 420; Ministry for the Environment: Wellington, New Zealand, 2002. Available online: http:/ /www.mfe.govt. $\mathrm{nz} /$ publications/rma/people-places-spaces-mar02 (accessed on 15 November 2018).

80. Ministry for the Environment. New Zealand Urban Design Protocol; ME Number 579; Ministry for the Environment: Wellington, New Zealand, 2005. Available online: http:/ / www.mfe.govt.nz/publications / towns-and-cities/new-zealand-urban-design-protocol (accessed on 15 November 2018).

81. Van Passel, S. Food miles to assess sustainability: A revision. Sustain. Dev. 2013, 21, 1-17. [CrossRef]

82. Hunt, D. Market gardening in metropolitan Auckland. N. Z. Geogr. 1959, 15, 130-155. [CrossRef]

83. Howden-Chapman, P. Home Truths: Confronting New Zealand's Housing Crisis; Bridget Williams Books: Wellington, New Zealand, 2015; Volume 37.

84. Greenhalgh, S.; Samarasinghe, O.; Curran-Cournane, F.; Wright, W.; Brown, P. Using ecosystem services to underpin cost-benefit analysis: Is it a way to protect finite soil resources? Ecosyst. Serv. 2017, 27, 1-14. [CrossRef]

85. Miller, S.; Tait, P.; Saunders, C. Estimating indigenous cultural values of freshwater: A choice experiment approach to Māori values in New Zealand. Ecol. Econ. 2015, 118, 207-214. [CrossRef]

86. Frenkel, A. The potential effect of national growth-management policy on urban sprawl and the depletion of open spaces and farmland. Land Use Policy 2004, 21, 357-369. [CrossRef]

(C) 2018 by the author. Licensee MDPI, Basel, Switzerland. This article is an open access article distributed under the terms and conditions of the Creative Commons Attribution (CC BY) license (http:/ / creativecommons.org/licenses/by/4.0/). 